\title{
Sub-specific differentiation of intestinal spirochaete isolates by macrorestriction fragment profiling
}

\author{
Sarah J. Rayment, ${ }^{1}$ Stephen P. Barrett ${ }^{2}$ and M. Anne Livesley ${ }^{1}$
} Author for correspondence: M. Anne Livesley. Tel: +44121 3593611 ext. 4770 . Fax: +44 1213590733.
e-mail : M.A.Livesley@aston.ac.uk

1 Department of Pharmaceutical and Biological Sciences, Aston University, Aston Triangle, Birmingham B4 7ET, UK

2 Department of Medical Microbiology, St Mary's Hospital Medical School, Norfolk Place, London W2 1PG, UK

\begin{abstract}
Macrorestriction fragment profile analysis by PFGE was used to distinguish intestinal spirochaetes, some of which were isolated from cases of swine dysentery and intestinal spirochaetosis in humans, pigs, mice, chickens and dogs. Macrorestriction fragment profiles using Smal and Sacll restriction enzymes were produced and used in statistical analysis. This permitted the division of the isolates into two major clusters. One cluster contained isolates which were identified as Serpulina pilosicoli and the second cluster contained isolates identified as Serpulina hyodysenteriae by immunoblotting with species-specific mAbs. Both species contained sub-specific groups, although these rarely correlated with the source of the isolates. We conclude that PFGE is capable of sub-specific differentiation of intestinal spirochaetes, but that the current species contain a large variety of genotypes among which crossspecies transmission may be feasible.
\end{abstract}

Keywords: intestinal spirochaete, pulsed-field gel electrophoresis, macrorestriction fragment profiling

\section{INTRODUCTION}

Spirochaetes involved in pathogenesis of intestinal disease are presently divided into two species, Serpulina byodysenteriae and Serpulina pilosicoli (Trott et al., 1996). S. hyodysenteriae is the aetiological agent of swine dysentery (Harris et al., 1972). S. pilosicoli, which is weakly $\beta$-haemolytic has been implicated in 'intestinal spirochaetosis' where the presence of spirochaetes in the gut has been associated with diarrhoea in pigs (Lee et al., 1993b), dogs (Duhamel et al., 1995), birds (McLaren et al., 1994) and humans (Lee \& Hampson, 1994).

A number of techniques have been used in the analysis of intestinal spirochaete isolates. Multilocus enzyme electrophoresis (MLEE) of exocellular enzymes demonstrated that certain porcine and human isolates of $S$. pilosicoli were related (Lee \& Hampson, 1994) whilst Coomassie-Blue-stained and $\left[{ }^{35} \mathrm{~S}\right]$ methionine-labelled SDS-polyacrylamide gels of whole-cell proteins showed great heterogeneity amongst human isolates (Barrett et al., 1996). There are two further proposed species 'Serpulina intermedius' (Lee et al., 1993a) and 'Serpulina murdochii' (Lee \& Hampson, 1994) defined

Abbreviations: MLEE, multilocus enzyme electrophoresis; UPGMA, unweighted-pair group method of arithmetic averages. on the basis of MLEE. The provisional designations of 'S. intermedius' and 'S. murdochii' were also applied to spirochaetes in the MLEE study of Stanton et al. (1996) although the strains of ' $S$. intermedius' showed 98$99.9 \%$ sequence identity with the $16 \mathrm{~S}$ rRNA genes of the reference isolates of $S$. byodysenteriae $\left(\mathrm{B} 78^{\mathrm{T}}\right)$ and Serpulina innocens $\left(\mathrm{B} 256^{\mathrm{T}}\right)$. Analysis of unclassified isolates of intestinal spirochaetes from humans and dogs has shown some to be closely related although whether intestinal spirochaetosis is a zoonosis has yet to be clarified (Duhamel et al., 1995; Koopman et al., 1993). PFGE has been used for sub-species differentiation of $S$. pilosicoli (Atyeo et al., 1996) and this study suggested the possibility of cross-species transmission, including zoonotic spread.

The main purpose of this investigation was to explore the genotypes of a large number of isolates of $S$. pilosicoli and $S$. byodysenteriae to examine sub-species variation and look for evidence of cross-species transmission. We also sought correlations between genotypes and sources of the isolates.

\section{METHODS}

Bacterial isolates and culture conditions. Sixty-eight isolates of intestinal spirochaetes were obtained from a number of sources (Table 1). These 68 isolates included 52 from humans, 
Table 1. Origin and source of the isolates used in this study

The numbers assigned to each isolate correspond with the numbers shown in Fig. 4. Numbers 1-58 are S. pilosicoli and 59-68 are S. byodysenteriae.

\begin{tabular}{|c|c|c|c|c|c|}
\hline No. & Isolate & Patient & Symptom & Source & Reference/supplier \\
\hline 1 & 1 & Human: male aged 2 & Diarrhoea, giardiasis & Oman & Barrett (1990) \\
\hline 2 & 26 & Human: male aged 10 & Diarrhoea, vomiting (1 d) & Oman & Barrett (1990) \\
\hline 3 & 3 & Human: male aged 50 & Abdominal pain & Oman & Barrett (1990) \\
\hline 4 & 4 & Human: male aged 50 & Giardiasis & Oman & Barrett (1990) \\
\hline 5 & $81 / 80$ & Human: male aged 69 & Stroke/hemiplegia & France & $\begin{array}{l}\text { Fournié-Amazouz } \\
\text { et al. (1995) }\end{array}$ \\
\hline 7 & HRM3 & Human: male aged 40 & Constipation/diarrhoea & Italy & Sanna et al. (1984) \\
\hline 8 & 19 & Human: female aged 5 & Diarrhoea & Oman & Barrett (1990) \\
\hline 9 & 47 & Human: female aged 40 & Abdominal pain for 6 months & Oman & Barrett (1990) \\
\hline 10 & 39 & Human: male aged 13 & Abdominal pain & Oman & Barrett (1990) \\
\hline 11 & 40 & Human: female aged 25 & Flatulence & Oman & Barrett (1990) \\
\hline 13 & 3941 & Human & Not known & $\begin{array}{l}\text { Oman, no } \\
\text { records kept }\end{array}$ & Barrett (1990) \\
\hline 14 & 64 & Human: male aged 27 & $\begin{array}{l}\text { Abdominal pain/backache } \\
\text { (3 years) }\end{array}$ & Oman & Barrett (1990) \\
\hline 15 & 6 & Human: male aged 50 & Abdominal pain/giardiasis & Oman & Barrett (1990) \\
\hline 16 & 17 & Human: female aged 35 & Not known & Oman & Barrett (1990) \\
\hline 17 & 13 & Human: female aged 2 & Diarrhoea for 2 weeks & Oman & Barrett (1990) \\
\hline 18 & $28 / 94$ & Human: male aged 55 & $\begin{array}{l}\text { Alcoholic with acute } \\
\text { intoxication with } \\
\text { ethylene glycol }\end{array}$ & France & $\begin{array}{l}\text { Fournié-Amazouz } \\
\text { et al. (1995) }\end{array}$ \\
\hline 19 & HRM16 & Human: male aged 22 & Not known & Italy & Sanna et al. (1984) \\
\hline 20 & 29 & Human: male aged 2 & Abdominal pain ( 1 month) & Oman & Barrett (1990) \\
\hline 21 & 37 & Human: female aged 30 & Headaches (6 years) & Oman & Barrett (1990) \\
\hline 22 & 18 & Human: female aged 26 & Diarrhoea and vomiting & Oman & Barrett (1990) \\
\hline 23 & 20 & Human: male aged 24 & Diarrhoea/abdominal pain & Oman & Barrett (1990) \\
\hline 24 & 31 & Human: female aged 10 & Chronic diarrhoea & Oman & Barrett (1990) \\
\hline 25 & 25 & Human: male aged 4 & Diarrhoea for 2 weeks & Oman & Barrett (1990) \\
\hline 26 & 32 & Human & Diarrhoea & $\begin{array}{l}\text { UK, AIDS } \\
\text { patient }\end{array}$ & S. Barrett \\
\hline 27 & 28 & Human: female aged 45 & Not known & Oman & Barrett (1990) \\
\hline 28 & 30 & Human: male aged 60 & Not known & Oman & Barrett (1990) \\
\hline 29 & 14 & Human: female aged 20 & Abdominal pain for 1 week & Oman & Barrett (1990) \\
\hline 30 & PE90 & Human: female aged 77 & Stroke/hemiplegia & France & $\begin{array}{l}\text { Fournié-Amazouz } \\
\text { et al. (1995) }\end{array}$ \\
\hline 31 & $128 / 90$ & Human: male aged 69 & Acute peritonitis & France & $\begin{array}{l}\text { Fournié-Amazouz } \\
\text { et al. (1995) }\end{array}$ \\
\hline 32 & PWS/B & Pig & Post-weaning scour & UK & IAH, Compton* \\
\hline 33 & 10 & Human: female aged 12 & $\begin{array}{l}\text { Acute lymphocytic } \\
\text { leukaemia/abdominal } \\
\text { pain/giardiasis }\end{array}$ & Oman & Barrett (1990) \\
\hline 34 & A3888 & Dog & Diarrhoea & Netherlands & Koopman (1992) \\
\hline 35 & 8 & Human: female aged 12 & Enuresis & Oman & Barrett (1990) \\
\hline 36 & 9 & Human: female aged 4 & Abdominal pain (1 year) & Oman & Barrett (1990) \\
\hline 37 & M15183 & Human: male aged 29 & Diarrhoea/abdominal pain & $\begin{array}{l}\text { Homosexual AIDS } \\
\text { patient, UK }\end{array}$ & S. Barrett \\
\hline 38 & A5660 & Dog & Diarrhoea & Netherlands & Koopman (1992) \\
\hline 39 & 60 & Human: male aged 3 & Diarrhoea and vomiting & Oman & Barrett (1990) \\
\hline 40 & RA87 & Human: male aged 62 & Severe arteriopathy & France & $\begin{array}{l}\text { Fournié-Amazouz } \\
\text { et al. (1995) }\end{array}$ \\
\hline
\end{tabular}


Table 1 (cont.)

\begin{tabular}{|c|c|c|c|c|c|}
\hline No. & Isolate & Patient & Symptom & Source & Reference/supplier \\
\hline 41 & 36 & Human: female aged 24 & $\begin{array}{l}\text { Abdominal pain/ } \\
\text { Shigella flexneri }\end{array}$ & Oman & Barrett (1990) \\
\hline 42 & Korlos & Human & Not known & $\begin{array}{c}\text { Australian } \\
\text { Aborigine }\end{array}$ & $\begin{array}{l}\text { Lee \& Hampson } \\
\text { (1992) }\end{array}$ \\
\hline 43 & 23 & Human: male aged 35 & Abdominal pain & Oman & Barrett (1990) \\
\hline 44 & A3077 & Dog & Diarrhoea & Netherlands & Koopman (1990) \\
\hline 45 & FT6 & Human & Diarrhoea & $\begin{array}{l}\text { AIDS patient, } \\
\text { UK }\end{array}$ & S. Barrett \\
\hline 46 & A5687 & Dog & Diarrhoea & Netherlands & Koopman (1992) \\
\hline 47 & Gel-2 & Human: male aged 31 & Diarrhoea & $\begin{array}{l}\text { Homosexual AIDS } \\
\text { patient, UK }\end{array}$ & S. Barrett \\
\hline 48 & Gel & Human: male aged 31 & Not known & $\begin{array}{l}\text { Homosexual AIDS } \\
\text { patient, UK }\end{array}$ & S. Barrett \\
\hline 49 & 38 & Human: female aged 45 & Abdominal pain/headache & Oman & Barrett (1990) \\
\hline 50 & Matthews & Human: child & Diarrhoea & $\begin{array}{l}\text { Australian } \\
\text { Aborigine }\end{array}$ & $\begin{array}{l}\text { Lee \& Hampson } \\
\text { (1992) }\end{array}$ \\
\hline 51 & $\mathrm{P} 43 / 6 / 78$ & Pig & Diarrhoea & UK & ATCC 51139 \\
\hline 52 & FT9 & Human & Not known & UK & S. Barrett \\
\hline 53 & FT7 & Human & Not known & UK & S. Barrett \\
\hline 54 & Wesley & Human : child & Diarrhoea & $\begin{array}{c}\text { Australian } \\
\text { Aborigine }\end{array}$ & $\begin{array}{l}\text { Lee \& Hampson } \\
\text { (1994) }\end{array}$ \\
\hline 55 & Jeremiah & Human: child & Diarrhoea & $\begin{array}{l}\text { Australian } \\
\text { Aborigine }\end{array}$ & $\begin{array}{l}\text { Lee \& Hampson } \\
\text { (1994) }\end{array}$ \\
\hline 56 & 44 & Human: male aged 29 & Diarrhoea & Oman & Barrett (1990) \\
\hline 57 & 57 & Human: male (child) & Not known & Oman & Barrett (1990) \\
\hline 58 & 35 & Human: female aged 28 & Fever, typhoid & Oman & Barrett (1990) \\
\hline 59 & B78 & Pig & Swine dysentery & USA & ATCC 27164 \\
\hline 60 & JWPM & Pig & Swine dysentery & Netherlands & $\begin{array}{l}\text { Lemcke \& Bew } \\
\text { (1984) }\end{array}$ \\
\hline 61 & B204 & Pig & Swine dysentery & USA & B. van der Zeijst \\
\hline 62 & $\mathrm{~A} 1$ (ST.4) & Pig & Swine dysentery & Netherlands & B. van der Zeijst \\
\hline 63 & 11416 & Chicken & Not known & Netherlands & IAH, Compton \\
\hline 64 & $\mathrm{P} 18 \mathrm{~A}$ & Pig & Swine dysentery & UK & IAH, Compton \\
\hline 65 & WT10/82 & Mouse & Not known & $\begin{array}{l}\text { Isolated from } \\
\text { farm with swine } \\
\text { dysentery, UK }\end{array}$ & IAH, Compton \\
\hline 66 & $\mathrm{C} 5$ & Pig & Diseased & Netherlands & ter Huurne (1993) \\
\hline 67 & A4 & Pig & Diseased & Netherlands & ter Huurne (1993) \\
\hline 68 & AF6/80 & Pig & Swine dysentery & UK & IAH, Compton \\
\hline
\end{tabular}

* Institute for Animal Health, Compton, Berkshire, UK.

10 from pigs, four from dogs, one from a chicken and one from a mouse. The isolates originated from the Muscat area of Oman ( $n=34)$, Australia $(n=4)$, UK $(n=12)$, Italy $(n=2)$, France $(n=5)$, USA $(n=2)$ and The Netherlands $(n=9)$. Isolates $5,18,30,31,40$ and 51 have previously been characterized as $S$. pilosicoli by Trott et al. (1997) and these isolates plus 48, 53 and 57 have been confirmed as $S$. pilosicoli using PCR to the $16 \mathrm{~S}$ rRNA gene (K. A. L. De Smet, D. E. Worth \& S. P. Barrett, personal communication). Isolates 59 and 61 were confirmed as $S$. byodysenteriae by the use of species-specific PCR (Elder et al., 1994). Spirochaetes were maintained in anaerobic conditions on Columbia agar base containing $5 \%(\mathrm{v} / \mathrm{v})$ horse blood. Spirochaetes were cultured anaerobically for DNA preparation in tryptone soya broth (Oxoid) containing $7.5 \%(\mathrm{v} / \mathrm{v}$ ) horse serum (Oxoid), $0.25 \%$ $(\mathrm{w} / \mathrm{v})$ glucose and $0.05 \%(\mathrm{w} / \mathrm{v})$ cysteine at $37^{\circ} \mathrm{C}$.

Preparation of high-molecular-mass genomic DNA. Highquality unsheared genomic DNA was prepared by embedding whole cells in chromosomal-grade agarose blocks then lysing the cells with detergent and proteinase K. Spirochaetes were harvested by centrifugation at $3000 \mathrm{~g}$ for $10 \mathrm{~min}$. Forty milligrams (wet weight) of intestinal spirochaetes resuspended in $1 \mathrm{ml} \mathrm{NET}-100$ were mixed with $1 \mathrm{ml}$ molten low-meltingpoint chromosomal-grade agarose $[0.9 \%(\mathrm{w} / \mathrm{v})$ in NET-100; Bio-Rad] and dispensed into plugs $(1 \times 9 \times 20 \mathrm{~mm})$. Agarose 
plugs were incubated $\left(24 \mathrm{~h}, 37^{\circ} \mathrm{C}\right)$ in lysis solution $[6 \mathrm{mM}$ Tris/ $\mathrm{HCl} \mathrm{pH} \mathrm{7.6,} 1 \mathrm{M} \mathrm{NaCl}, 100 \mathrm{mM}$ EDTA, $0.5 \%$ (w/v) Nlauroyl sarcosine, $1 \mathrm{mg}$ lysozyme $\mathrm{ml}^{-1}$ ] followed by proteinase $\mathrm{K}$ treatment $\left(48 \mathrm{~h}, 50^{\circ} \mathrm{C}\right)$ in ESP [0.5 M EDTA pH 9.0 containing $1 \%(\mathrm{w} / \mathrm{v}) \mathrm{N}$-lauroyl sarcosine and $1.5 \mathrm{mg} \mathrm{m}^{-1}$ proteinase $\mathrm{K}$ (Boehringer)]. Agarose plugs were stored in ESP at $4{ }^{\circ} \mathrm{C}$ prior to TE (10 mM Tris/ $\mathrm{HCl} \mathrm{pH} \mathrm{8.0,1} \mathrm{mM} \mathrm{EDTA)}$ washing as described by Maslow et al. (1993).

Restriction digestion of DNA and PFGE. Rare-cutting restriction enzymes Smal ( $5^{\prime}$ CCCGGG) and SacII (5'CCGCGG) were used to cleave the intestinal spirochaete genome. Portions $(1 \times 1 \times 9 \mathrm{~mm})$ of agarose plugs containing high-molecularmass DNA were incubated for $15 \mathrm{~min}$ in restriction buffer (as supplied by the enzyme manufacturer) at $0-4^{\circ} \mathrm{C}$, the buffer was then replaced with buffer containing 40 units restriction enzyme and the $0-4{ }^{\circ} \mathrm{C}$ incubation repeated followed by $24 \mathrm{~h}$ incubation at the recommended temperature for the enzyme. The digested slivers were incubated at $50^{\circ} \mathrm{C}$ for $20 \mathrm{~min}$ in ES [0.5 M EDTA pH 9.0 containing $1 \%(\mathrm{w} / \mathrm{v}) \mathrm{N}$-lauroyl sarcosine] followed by one wash in TE for $15 \mathrm{~min}$ and subjected to PFGE in $0.5 \times \mathrm{TBE}(1 \times \mathrm{TBE}$ is $90 \mathrm{mM}$ Tris-borate and $1 \mathrm{mM}$ EDTA pH 8.0 ) through $1 \%$ agarose (Bio-Rad) with a ramped pulse time of $10-60$ seconds for $22 \mathrm{~h}$ then $70-90 \mathrm{~s}$ for $2 \mathrm{~h}$ using a Bio-Rad CHEF DR III apparatus at a temperature of $10^{\circ} \mathrm{C}$.

Gels were stained using $0.5 \mu \mathrm{g}$ ethidium bromide $\mathrm{ml}^{-1}$ for $30 \mathrm{~min}$, de-stained in distilled water and visualized using a scanner (UVP Products).

Evaluation of pulsed-field gels. Band sizes were estimated using the Gelworks 1D software package (UVP products). At least two independent separations of the restriction fragments were performed to ensure reproducibility. Levels of relatedness of the isolates were determined by comprehensive pairwise comparisons of macrorestriction fragment sizes using the Dice coefficient $\left(S_{\mathrm{D}}\right)$. The $S_{\mathrm{D}}$ value is the ratio of twice the number of bands which each pair of restriction profiles has in common to the total number of fragments in each profile (Grothues \& Tummler, 1991):

$S_{\mathrm{D}}=2 n_{\mathrm{i}} /\left(n_{\mathrm{A}}+n_{\mathrm{B}}\right)$

where $n_{\mathrm{A}}$ and $n_{\mathrm{B}}$ are the numbers of fragments in patterns $\mathrm{A}$ and $\mathrm{B}$, respectively, and $n_{1}$ is the number of common fragments. Mean values of $S_{\mathrm{D}}$ obtained were used in the UPGMA (unweighted-pair group method of arithmetic averages) software (Unistat version 4.0) to generate dendrograms of relatedness as described by Rainey et al. (1994).

SDSPAGE. Separation of whole cell spirochaete proteins was carried out in the Mini-PROTEAN system (Bio-Rad) using a $12 \%(\mathrm{v} / \mathrm{v})$ acrylamide separating gel and a $3 \%(\mathrm{v} / \mathrm{v})$ stacking gel (Laemmli, 1970).

Immunoblotting. Proteins were transferred from SDS-PAGE gels to nitrocellulose membranes $(0.45 \mu \mathrm{m}$ pore size, Bio-Rad) using a Mini-Transblot cell (Bio-Rad) (Towbin et al., 1979). Two intestinal spirochaete-specific mAbs were used in this study: BJL/AC1, specific for a $29 \mathrm{kDa}$ protein of $S$. pilosicoli (Lee \& Hampson, 1995) and BJL/SH1, specific for a $30 \mathrm{kDa}$ protein of $S$. hyodysenteriae (Lee \& Hampson, 1996). Blots were visualized using anti-mouse IgG conjugated to horseradish peroxidase (Sigma) followed by development with $0.01 \%(\mathrm{v} / \mathrm{v})$ hydrogen peroxide and 4-chloro-1-naphthol $\left(25 \mu \mathrm{g} \mathrm{ml}^{-1}\right.$ in $10 \mathrm{mM}$ Tris/ $\mathrm{HCl} \mathrm{pH} \mathrm{7 \cdot 4).}$

\section{RESULTS}

\section{Identification of intestinal spirochaetes as S. pilosicoli or S. hyodysenteriae}

The specificity of the two mAbs is illustrated in Fig. 1. Isolates $1-58$ reacted with the $S$. pilosicoli-specific $m A b$. Isolates 59-68 were shown to react with species-specific $\mathrm{mAb}$ to $S$. hyodysenteriae.

\section{Quantitative evaluation of macrorestriction fragment profiles}

SmaI and SacII were used to cleave the intestinal spirochaete genome into few fragments (Table 2). Other enzymes investigated (XbaI 5'TCTAGA, NaeI 5 'GCCGGC) cut the genome into too many fragments to be useful in pairwise comparisons. Five isolates including Brachyspira aalborgi (Hovind-Hougen et al., 1982) yielded too few fragments with SmaI and SacII to be used in the statistical analyses and were therefore removed from the study. The size of the whole intestinal spirochaete genome was estimated to be approximately 2.6-3 Mb using PFGE following digestion with Not $\mathrm{I}$ which has a single restriction site (Zuerner \& Stanton, 1994). For each isolate the approximate genome size was obtained by adding together the sizes of the resolved restriction fragments and was found to be $3 \mathrm{Mb}$. Fig. 2 shows the discriminatory value of the enzymes used in this study. Two isolates from a UK male homosexual (47 and 48) showed identical macrorestriction fragment profiles; otherwise substantial variation amongst the isolates was observed. Fig. 3 illustrates the discriminatory power of using two restriction enzymes to restrict the genomic DNA. (a) B204

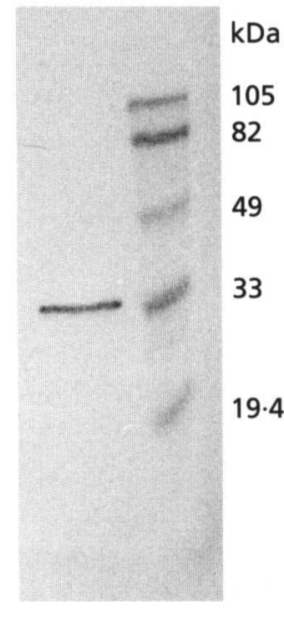

(b) A5687

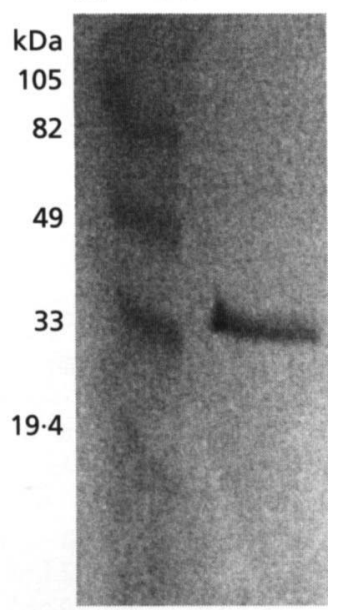

Fig. 1. SDS-PAGE immunoblot of representative isolates of $S$. hyodysenteriae and $S$. pilosicoli probed with the species-specific mAbs BJLSH1 (a) and BJUAC1 (b). Molecular mass standards are shown in $\mathrm{kDa}$. 
Table 2. Macrorestriction fragment sizes (kb) from Smal and Sacll restriction digests of representative isolates from each of the clusters in Fig. 4

\begin{tabular}{|llll|}
\hline Cluster & Strain & \multicolumn{1}{c|}{ SacII } & \multicolumn{1}{c|}{ SmaI } \\
\hline 1A & 26 & $984,585,256,202,136,62,49$ & $579,382,341,329,200,115,81,52$ \\
1B & HRM3 & $964,726,426,270,214,163,112$ & $693,384,365,323,123,101,64$ \\
1B & 32 & $875,542,143,88$ & $951,570,447,416,374,270,99,63$ \\
1B & PWS/B & $884,743,452,216,185,160,102,82$ & $905,868,705,320,257,177,132,102$ \\
1C & RA87 & $820,569,230,194,184,141,73,57$ & $909,476,300,123,94,69,56$ \\
1D & Gel-2 & $953,482,424,230,151,138,114,56,47$ & $649,373,325,129,117,108,99$ \\
1E & 44 & $582,468,433,387,205,182,152,119$ & $674,441,358,296,251,220,135,104,89,66$ \\
2 & B78 & $734,508,348,309,263,209,118,54,47,40,33$ & $960,252,223,83$ \\
\hline
\end{tabular}

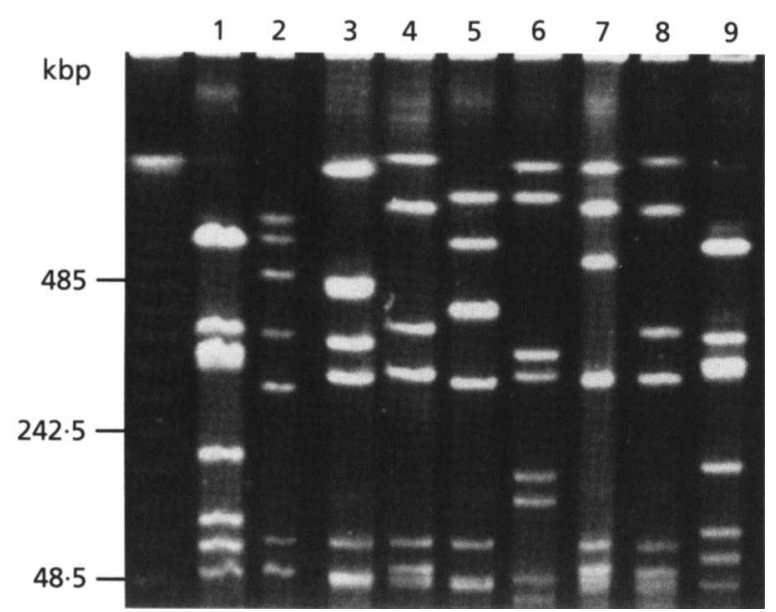

Fig. 2. Variation in macrorestriction fragment profiles from Smal-digested human isolates of $S$. pilosicoli isolated in Muscat, Oman. Lanes 1-9 correspond to isolates $1,3,4,6,9,10,12,17$ and 26 from Table 1 . The sizes of co-migrating $\lambda$ concatamers are shown in kbp on the left.

\section{Division of the isolates into two major clusters}

The levels of similarity of the profiles were determined by pairwise comparisons and quantified using $S_{\mathrm{D}}$. The dendrogram in Fig. 4 shows two clusters at or below 1.8 Euclids. The range of macrorestriction fragment sizes of representative isolates in each of the clusters in Fig. 4 is shown in Table 2 for both Smal and SacII.

\section{DISCUSSION}

Application of PFGE to intestinal spirochaete isolates has confirmed the genomic heterogeneity of intestinal spirochaetes as a group and, more particularly, heterogeneity within S. pilosicoli (Atyeo et al., 1996; Lee \& Hampson, 1994). Cluster 1 contains isolates shown to be $S$. pilosicoli upon immunoblotting which are genotypically different, suggesting that specific division of $S$. pilosicoli may be possible. This cluster was subdivided into five groups (A, B, C, D, E), all of which contain Omani human isolates. Few correlations could be made between the geographical origin of isolates and their genotype and it is noteworthy that human isolates collected in a limited area such as the city of Muscat in Oman were represented in almost every group within cluster 1 .

Groups $\mathrm{A}$ and $\mathrm{E}$ of cluster 1 contained exclusively Omani isolates with group A including the Omani isolate 26 (2) which formed a separate branch in the study of Hookey et al. (1994). Group B contained the majority of the human isolates examined in this study. Groups C and D contained isolates from a wide range of sources confirming the sub-specific heterogeneity of S. pilosicoli.

The French bacteraemic isolates $(5,18,30,31,40)$ (Fournié-Amazouz et al., 1995) included in the study did not cluster together suggesting that the bacteraemic property cannot be correlated with genotype, although the number of isolates examined was small. Trott $e t$ al. (1997) also demonstrated that the French bacteraemic isolates did not cluster together using MLEE. The two isolates 47 and 48 were obtained at different times from the same male homosexual and had identical macrorestriction fragment profiles, demonstrating that the colonization with spirochaetes was stable and persistent. The persistence of colonization has also been shown in Aboriginal children (Lee \& Hampson, 1992) and with $S$. byodysenteriae in pigs (Neef et al., 1994) and mice (Clark, 1984). The identical patterns obtained with the two isolates from a male homosexual suggest either that a long-term colonization occurred or that the patient was repeatedly infected with a single clone of spirochaetes. Other populations of spirochaetes may have been present in this patient and may not have been selected by the isolation procedure used. Three further isolates which were included from male homosexuals had different genotypes $(45,44,51)$. Further studies would need to be carried out to establish whether male homosexuals were predisposed to infection with specific genotypes. No correlation could be found between disease manifestation and genotype in S. pilosicoli. 


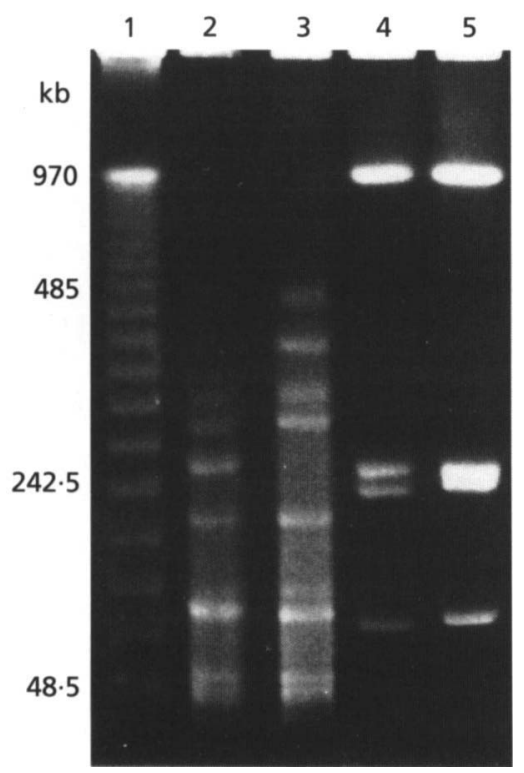

Fig. 3. PFGE illustrating the discriminatory power of the restriction enzymes Sacll (lanes 2 and 3) and Smal (lanes 4 and 5 ) on two isolates, JWPM (60) and B78 (59), used in this study.

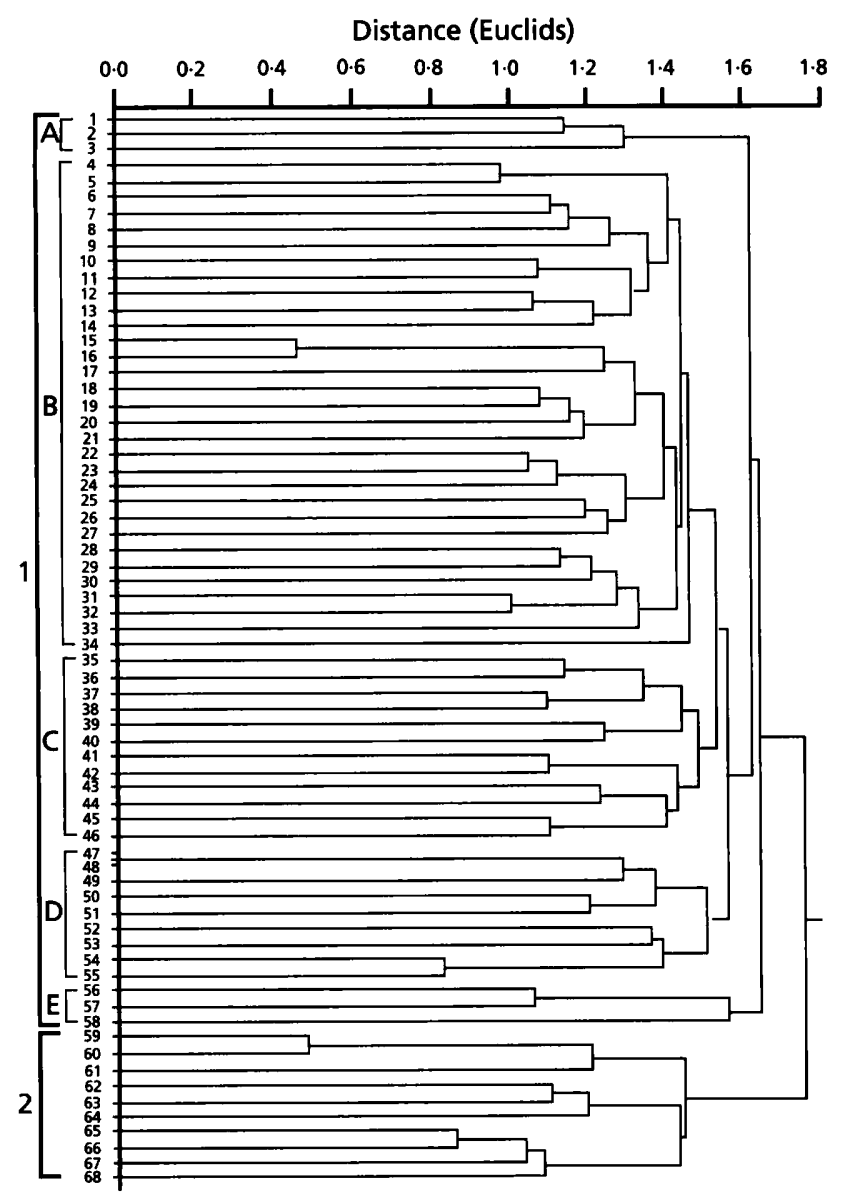

Fig. 4. Dendrogram of intestinal spirochaete isolates generated by cluster analysis of macrorestriction fragment profiles using UPGMA.
In group C, the dog isolate A5687 (46) and the human isolate FT6 (45) showed similar profiles, diverging at a distance of 1.1 Euclids suggesting that cross-species transmission is feasible.

Cluster 2 contains 10 isolates confirmed as $S$. byodysenteriae using the $\mathrm{BJL} / \mathrm{SH} 1 \mathrm{mAb}$. This group of isolates consisted predominately of pig isolates. Isolates 59 and 60 were sufficiently similar for discrimination to have occurred with only one of the restriction enzymes used in this study (SacII) (Fig. 3). Evidence was found that the profiles of the $S$. byodysenteriae isolates showed some conserved fragments, suggesting that $S$. hyodysenteriae may be more conserved as a species than S. pilosicoli.

In conclusion, the heterogeneity of $S$. pilosicoli may reflect niche selection within a certain type of host, although there is no correlation between host specificity and genotype. Some evidence of cross-species transmission is suggested. Macrorestriction fragment profiling of intestinal spirochaetes has demonstrated subspecific differentiation of isolates into heterogeneous groups, particularly in the case of $S$. pilosicoli.

\section{ACKNOWLEDGEMENTS}

We are grateful to G. Dettori, D. Hampson, I. Saint Girons and B. van der Zeijst for making their isolates available for study. We thank D. Hampson for the gift of mAbs. We thank $M$. Burrows for culturing isolates and P. Lambert for critical reading of the manuscript. S. J.R. was supported by a BBSRC studentship.

\section{REFERENCES}

Atyeo, R. F., Oxberry, S. L. \& Hampson, D. J. (1996). Pulsed-field gel electrophoresis for sub-specific differentiation of Serpulina pilosicoli (formerly 'Anguillina coli'). FEMS Microbiol Lett 141, 77-81.

Barrett, S. P. (1990). Intestinal spirochaetes in a Gulf Arab population. Epidemiol Infect 104, 261-266.

Barrett, S. P., Holton, J. J. M., Hookey, J. V., Costas, M., Ganner, M., Mundy, R. \& Wright, D. J. M. (1996). Heterogeneity of human intestinal spirochaetes demonstrated by one dimensional polyacrylamide gel electrophoresis of proteins visualized by ${ }^{35} \mathrm{~S}$ methionine labelling and Coomassie blue staining. $J$ Med Microbiol 45, 6-9.

Clark, J. D. (1984). Biology and diseases of other rodents. In Laboratory Animal Medicine, pp. 183-205. Edited by J. G. Fox, B. J. Cohen \& F. M. Loew. Orlando, FL: Academic Press.

Duhamel, G. E., Muniappa, N., Mathiesen, M. R., Johnson, J. L., Toth, J., Elder, R. O. \& Doster, A. R. (1995). Certain canine weakly $\beta$-hemolytic intestinal spirochetes are phenotypically and genotypically related to spirochetes associated with human and porcine intestinal spirochetes. J Clin Microbiol 33, 2212-2215.

Elder, R. O., Duhamel, G. E., Schafer, R. W., Mathiesen, M. R. \& Ramanathan, M. (1994). Rapid detection of Serpulina byodysenteriae in diagnostic specimens by PCR. J Clin Microbiol 32, 1497-1502. 
Fournié-Amazouz, E., Baranton, G., Carlier, J. P., Chambreuil, G., Cohadon, F., Collin, P., Gougeon Jolivet, A., Hermes, I., Lemarie, C. \& Saint Girons, I. (1995). Isolation of intestinal spirochaetes from the blood of human patients. J Hosp Infect 30, 160-162.

Grothues, D. \& Tummler, B. (1991). New approaches in genome analysis by pulsed-field gel electrophoresis: application to the analysis of Pseudomonas species. Mol Microbiol 5, 2763-2776.

Harris, D. L., Glock, R. D., Christensen, C. R. \& Kinyon, J. M. (1972). Inoculation of pigs with Treponema hyodysenteriae (new species) and reproduction of the disease. Int Vet Med Small Anim Clin 67, 61-64.

Hookey, J. V., Barrett, S. P., Reed, C. S. \& Barber, P. (1994). Phylogeny of human intestinal spirochaetes inferred from $16 \mathrm{~S}$ rRNA sequence comparisons. FEMS Microbiol Lett 117, 345-350.

Hovind-Hougen, K., Birch-Anderson, A., Henrik-Nielsen, R., Orholm, M., Pedersen, J. O., Teglbjaerg, P. S. \& Thaysen, E. H. (1982). Intestinal spirochetosis: morphological characterization and cultivation of the spirochete Brachyspira aalborgi gen. nov., sp. nov. J Clin Microbiol 16, 1127-1136.

ter Huurne, A. (1993). Swine dysentery: pathogenesis and vaccine development. $\mathrm{PhD}$ thesis, University of Utrecht.

Koopman, M. B. H. (1990). Characterization of derpulina hyodysenteriae periplasmic flagella and bemolysin. PhD thesis, University of Utrecht.

Koopman, M. B. H., Baats, E., de Leeuw, O. S., van der Zeijst, B. \& Kusters, J. G. (1993). Molecular analysis of a flagellar core protein gene of Serpulina (Treponema) byodysenteriae. J Gen Microbiol 139, 1701-1706.

Laemmli, U. K. (1970). Cleavage of structural proteins during the assembly of the head of bacteriophage T4. Nature 227, 680-685.

Lee, J. I. \& Hampson, D. J. (1992). Intestinal spirochaetes colonizing Aborigines from communities in the remote north of Western Australia. Epidemiol Infect 109, 133-141.

Lee, J. I. \& Hampson, D. J. (1994). Genetic characterization of intestinal spirochaetes and their association with disease. $J \mathrm{Med}$ Microbiol 40, 363-371.

Lee, B. J. \& Hampson, D. J. (1995). A monoclonal antibody reacting with the cell envelope of spirochaetes isolated from cases of intestinal spirochaetosis in humans and pigs. FEMS Microbiol Lett 131, 179-184.

Lee, B. J. \& Hampson, D. J. (1996). Production and characterization of a monoclonal antibody to Serpulina byodysenteriae. FEMS Microbiol Lett 136, 193-197.

Lee, J. I., Hampson, D. J., Lymbery, A. J. \& Harders, S. J. (1993a). The porcine intestinal spirochaetes: identification of new groups. Vet Microbiol 34, 273-285.
Lee, J. I., McLaren, A. J., Lymbery, A. J. \& Hampson, D. J. (1993b). Human intestinal spirochetes are distinct from Serpulina byodysenteriae. J Clin Microbiol 31, 16-21.

Lemcke, R. M. \& Bew, J. (1984). Antigenic differences amongst isolates of Treponema byodysenteriae. In Proceedings of the 8th Pig Veterinary Society Congress, Ghent, Belgium, p. 183.

McLaren, A. J., Trott, D. J., Swayne, D. E., Stoutenberg, J. W. \& Hampson, D. J. (1994). Characterization of avian intestinal spirochaetes. Proceedings of the 45th North Central Avian Disease Conference, Des Moines, IA, USA, p. 66.

Maslow, J. N., Slutsky, A. M. \& Arbeit, R. D. (1993). Application of pulsed field gel electrophoresis to molecular epidemiology. In Diagnostic Molecular Microbiology: Principles and Applications, pp. 563-572. Edited by D. H. Persing, T. F. Smith, F. C. Tenover \& T. J. White. Washington, DC: American Society for Microbiology.

Neef, N. A., Lysons, R. J., Trott, D. J., Hampson, D. J., Jones, P. W. \& Morgan, P. H. (1994). Pathogenicity of porcine intestinal spirochaetes in gnotobiotic pigs. Infect Immun 62, 2395-2403.

Rainey, P. B., Thompson, I. P. \& Palleroni, N. J. (1994). Genome and fatty acid analysis of Pseudomonas stutzeri. Int J Syst Bacteriol 44, 54-61.

Sanna, A., Dettori, G., Agliano, A. M., Branca, A. M., Grillo, R., Leone, F., Rossi, A. \& Parisi, G. (1984). Studies of treponemes isolated from the gastrointestinal tract. $\lg \operatorname{Mod} 81$, 959-973.

Stanton, T. B., Trott, D. J., Lee, J. I., McLaren, A. J., Hampson, D. J., Paster, B. J. \& Jensen, N. S. (1996). Differentiation of intestinal spirochaetes by multilocus enzyme electrophoresis analysis and $16 S$ rRNA sequence comparisons. FEMS Microbiol Lett 136, 181-186.

Towbin, H., Staehlin, T. \& Gordon, J. (1979). Electrophoretic transfer of proteins from polyacrylamide gels to nitrocellulose sheets : procedure and some applications. Proc Natl Acad Sci USA 76, 4350-4354.

Trott, D. J., Stanton, T. B., Jensen, N. S., Duhamel, G. E., Johnson, J. L. \& Hampson, D. J. (1996). Serpulina pilosicoli sp. nov., the agent of porcine intestinal spirochaetosis. Int J Syst Bacteriol 46, 206-215.

Trott, D. J., Jensen, N. S., Saint Girons, I., Oxberry, S. L., Stanton, T. B., Lindquist, D. \& Hampson, D. J. (1997). Identification and characterization of Serpulina pilosicoli isolates recovered from the blood of critically ill patients. J Clin Microbiol 35, 482-485.

Zuerner, R. L. \& Stanton, T. B. (1994). Physical and genetic map of the Serpulina byodysenteriae $\mathrm{B} 78^{\mathrm{T}}$ chromosome. J Bacteriol 176, 1087-1092.

Received 9 December 1996; revised 12 May 1997; accepted 23 May 1997. 